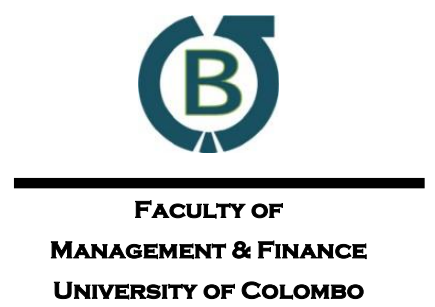

Colombo

Business

Journal

INTERNATIONAL JOURNAL OF

THEORY \& PRACTICE

Vol. 12, No. 01, June, 2021

\title{
Tackling Investment Risks Using Equity Options During Extreme Economic Upheavals: Indian Evidence
}

\author{
Babu Jose ${ }^{\mathrm{a}}$, James Varghese ${ }^{\mathrm{a}} \bowtie$ \\ ${ }^{a}$ Department of Commerce, St. Thomas College, Palai, India
}

\begin{abstract}
The study is an empirical scrutiny on the Indian equity options market to examine whether it facilitates the reduction of investment risks, focusing on an economic sphere with financial upheavals. The risk mitigation ability is examined with respect to the integration of nearmonth call and put options markets having different levels of exercisability with the equity market in the National Stock Exchange of India. The optimal size of options contracts required for establishing a hedge portfolio that minimises the risk exposure to a maximum possible magnitude and the level of gains resulting from such hedges are identified following the minimum variance approach, using Diagonal BEKK GARCH. The results indicate that ATM, ITM, and DITM call options and ATM, OTM, DOTM, and DITM put options provide effective risk reduction that can be efficiently utilised by the existing as well as prospective investors in the equity market.
\end{abstract}

Keywords: Optimal Risk Reduction, Minimum Variance Hedge Ratio, Financial Upheavals, Diagonal BEKK GARCH Model, Indian Equity Options Market

Received: Accepted revised version: Published:

27 August 2020

12 March 2021

30 June 2021

Suggested citation: Jose, B. \& Varghese, J. (2021). Tackling investment risks using equity options during extreme economic upheavals: Indian evidence. Colombo Business Journal, $12(1), 1-28$.

DOI: http://doi.org/10.4038/cbj.v12i1.69

(C) 2021 The Authors. This work is licensed under a Creative Commons Attribution 4.0 International License which permits unrestricted use, distribution, and reproduction in any medium, provided the original work is properly cited.

凶jvstcp@gmail.com (iD https://orcid.org/0000-0002-0518-2734 


\section{Introduction}

The presence of financial markets that facilitate diverse segments in it to enable the protection of productive investments is essential for the growth and expansion of any modern economic sphere. Explicitly, the efficacy of an equity market is supported by active derivative segments for expediting mitigation of price risks in it (Ross, 1976). Derivatives are financial instruments that inherently facilitate the transmission of uncertainties from the risk-averse investors to speculators who are risk lovers (Ederington, 1979). The options, being the most dynamic derivative with its capacity to be exercised at the preference of its holder, is expected to bring effective risk mitigation, as it appeals not to compromise the potential benefits from advantageous ups and downs in the underlying market. The risk reduction ability of a derivative market is identifiable from its long-lasting substantive relationship with the underlying asset market and from the persistence of such integration even when there are asymmetric movements in both the markets (Booth et al., 1999). The effectiveness of the risk dilution is measurable from the estimation of the optimal hedge size and the resulting hedge gains (Hull \& White, 2017).

Chang et al. (2010) noted that the effectiveness of optimum risk reduction varies as per differences in the market trends. Financial upheavals demarcate a crucial phase in the equity market, as they lead to the rallying of bears that provides cautious and pessimistic attitudes to the investors (Maheu et al., 2012). The Indian financial system witnessed such incalculable economic disruption with the outburst of global economic slowdown during the latter half of the first decade in the new millennium, and its effects were extremely evident in the Indian equity segment from January to October 2008 with a drastic fall of the market indicators (NSE Nifty 50) up to 52.50\% within 10 months. The unanticipated downturn of prices is the riskiest situation for the equity investors, and it is high time for the use of risk reduction mechanisms. The financial system that undergoes unprecedented recession when the equity market expresses a high propensity to drop, making the existing as well as prospective investors in the equity market cautious about using either call or put options separately or combinations of them to generate constructive gains from the deteriorations experienced in the value of their assets. This is mainly due to the fact that the options market is likely to exhibit high levels of information content and predictive power during such an economic scenario (Conover \& Peterson, 1999; Kim et al., 2013; Mazouz et al., 2015).

In a financial market that deteriorates in asset values, the call options appear to facilitate the investors to have an upper bound for longing in the asset (Bhattacharya, 1987), limiting the potential cash outlay to a maximum extent, where the investors 
use the options to minimise the impacts from unforeseen upsurges in prices while attempting to explore the lowest prices. Even amongst the idiosyncratic noise (Hull \& White, 2017), put options market seems to be a reservoir of substantial information in a bearish market (Kim et al., 2009), which can be effectively utilised for estimating the further downfall and the probable bottom level in the underlying market. Thus, an evaluation of both the call and put options develop value to future investors and existing investors, respectively, especially in a bearish market. Further, depending upon the risk preferences of the investors and their ability to spend for hedge related transactions based on estimated market fluctuations, the options market provide the investors with contracts falling under different exercisability levels (Bond \& Thompson, 1985; Pan et al., 2014; Yang et al., 2017).

Therefore, the objectives of the study are to explore the potential of the Indian equity options market for risk dilution and to estimate probable gains from hedging the equity investment risks from the use of equity options at an optimal level. The empirical evaluation further considers both the call and put options with varying levels of exercisability, with particular emphasis on a phase of bear domination in the equity market. The risk reduction ability of each of the options segments is examined by testing the null hypothesis that 'the equity options market in India is hardly ever in integration with the underlying equity market'. The present study contributes to the finance literature by suggesting an empirical methodology to develop time series representations for signifying the options market as a whole since the readily available data are from each of the options contracts being traded in the market. Further contributions of the current study are twofold. Initially it gives an estimation of optimal positions that account for mitigation of risks in the underlying market to the maximum possible magnitude by the use of different segments of the Indian equity options market. Then it assesses the level of gains resulting from such optimal positions using the minimum variance framework unlike frequent empirical evidence in the options hedging that uses pricing models for the estimations.

The rest of the paper includes a survey of empirical literature in the related fields of study, an elaboration on the methodology used, a detailed discussion on pragmatic implications of significant findings of the study, and a conclusion.

\section{Review of Literature}

\section{Relative Informational Efficiency of the Options and Stocks}

The risk reduction ability of the options market is connected to the theory of market efficiency that holds the market to be efficient when it leaves no excess returns 
to the market participants (Fama, 1970). The prediction of the actual options premium using theoretical pricing models was the early method of testing the efficiency of the options market (Evnine \& Rudd, 1984). Later this efficiency was tested by exploring the no-arbitrage association among different options segments or between the options market and its underlying market such as put-call parity, monotonicity property and no-arbitrage boundaries (Kamara \& Miller, 1995; Kumar \& Raman, 2017; Mittnik \& Rieken, 2000; Mutum \& Das, 2019; Vipul, 2008) and further by testing no-arbitrage relationship existing within the options market itself including put and call spread, box spread and butterfly spread (Ackert \& Tian, 2001; Aggarwal \& Gupta, 2009; Mohanti \& Priyan, 2014; Zhang \& Watada, 2019). But mere efficiency hardly ever warrants risk mitigation by the options market when it fails to confirm instantaneity with the underlying market in absorption and reflection of information (Chan et al., 1993). The absence of such simultaneous informational integration creates an effect that one market leads the other in the price discovery process, and it results in arbitrage profits (Booth et al., 1999; Hentze \& Seiler, 2000). Even if the lead-lag structure depends on inconsistencies and frictions in the markets (Abhyankar, 1995), the economic incentives of options trading, such as lower transaction costs and higher leverage, liquidity, and flexibility (Chakravarthy et al., 2004; Easley et al., 1998; Fleming et al., 1996; Harvey \& Whaley, 1992; Hentze \& Seiler, 2000; Kumar et al., 1995) falsify the notion that the options reflect only those information that is already reflected in the stock market, and suggest that there is significant information share with the options market (Baltussen et al., 2012). This is due to the informed investors who trade first in the options market to take advantage of their information (Kang \& Park, 2014), and cumulative transactions by them make the options market a rich reservoir of information on future stock movements (Ryu, 2016), providing directional information to traders in equity (Du \& Fung, 2018). It is also worth noting that there is empirical evidence for the leading price discovery roles of the equity market relative to the options counterparts. Conover and Peterson (1999), Chiang and Fong (2001), Chan et al. (2002), Kim et al. (2009), Chan et al. (2009), Muravyev et al. (2013) and Mazouz et al. (2015) are some studies among those presenting such evidence. The Indian evidence on the lead-lag structure among the options and equity markets also remains inconclusive. The early evaluations based on non-price variables in the markets prove that trade volume and open interest of stock options contained information to predict future price movements in the underlying stocks (Srivastava, 2003; Mukharjee \& Mishra, 2004). When Debasish (2009) proves that futures and options lead the stock market, Bagchi (2012) argues that the stock options have price discovery roles towards the stock market. However, some of the recent pieces of evidence indicate that the stock market is strong enough to have the price discovery in it (Dixit et al., 2010; Shaikh \& Padhi, 2013; 2015). 
The persistence of relative rate of information absorption in the options and equity markets is conditional on market circumstances and other sensitivities (Ren et al., 2019). Therefore, the risk reduction ability of the options during periods of financial turmoil in the economy can be assured, only when it moves together with the underlying market. This co-movement provides the investors a chance to offset the uncertainties in the equity market by opting for a reverse position in the options market (Bakshi et al., 2000b; Hull \& White, 2017). Therefore, one of the major prerequisites for considering options market to minimise the aftereffects of uncertain vicissitudes in the underlying market is the integration of both the market counterparts. However, the risk reduction ability can be confirmed only by identifying how effectively each of these markets interacts with the other, to initiate the process of bringing back the equilibrium through rectification of the aberrations, and to nullify the consequences from non-simultaneous absorption of information among the market streams (Kim et al., 2009).

\section{Optimal Hedging and Hedging Effectiveness}

The investors can reduce their risks in the spot market to the maximum possible extent by choosing an optimal position in the options market (Choudhry, 2004), and the magnitude of risk reduction measured in terms of gains from hedging denotes the effectiveness of the market (Cao \& Huang, 2007; Hull \& White, 2017). Using options at an optimal level for risk dilution transactions upsurge the efficacy of the hedging strategy (Kamara \& Siegel, 1987), and the selection of the optimal level purely depends upon the attitude of the investors towards risk (Bond \& Thompson, 1985). The mode of measuring hedging gains is also significant from the practitioner's point of view (Brailsford et al., 2001). The seminal work of Ederington (1979) proposed the hedge ratio that minimises the variance of the portfolio to be effective, considering the purpose of hedging is to create an optimum combination of risk and return, and Cecchetti et al. (1988) proposed the utility maximisation hedge. However, hedge ratios under diverse approaches converge into the ratio under minimum variance approach, when both the spot and derivative markets are jointly normal (Chen et al., 2003), especially in the case of longer hedging horizons (Chen et al., 2008).

Empirical evidence from the options market on its hedging effectiveness is relatively limited. Considering the hedge ratio as an integral part of the options pricing models, Bakshi et al. (1997; 2000a), Dumas et al. (1998), Buraschi and Jackwerth (2001), and An and Suo (2009) evaluate the hedging performance of different option pricing models. Rao and Thakur (2008) find that the methodologies proposed by Ederington (1979) and Black and Scholes (1973) outperform the other 
models for Indian futures and options, respectively. DeMaskey (1995), Bakshi et al. (2000a), Butterworth and Holmes (2001), Alexander and Nogueira (2007), and Hull and White (2017) support the appropriateness of the minimum variance approach in the estimation of gains from options hedging. More importantly, the empirical discussions on hedging using equity options stray around the strategies for options traders who take short positions in options market (Alexander et al., 2009; Alexander \& Nogueira, 2007; Hull \& White, 2017). Further, the deliberations from the hedgers' perspective are limited to commodity options (Alexander et al., 2013).

\section{Methodology}

One of the recent financial meltdowns experienced by the world economies is the global financial crisis that commenced with the US subprime crisis that took place between the years of 2007 and 2010. The Indian stock market also tasted the bitterness of this financial slowdown, but the period of the crisis was limited to a period from $15^{\text {th }}$ of January 2008 to $31^{\text {st }}$ of October 2008, and these 197 days are considered for the analysis. The variables needed for examining the risk reduction ability and effectiveness of the optimal risk reduction using the options market for the stock market investments are the representatives of the stock market and the equity options market in India, and they are actual index and implied index, respectively. The daily closing level of the NSE Nifty 50 index is the actual index, and the value of the index implied from the daily closing values of the equity options on the Nifty 50 index is the implied index levels to represent the equity options market (Debasish, 2009). Manaster and Rendleman (1982) proposed the concept of implied stock level in the finance literature, based on a presumption that the options are capable of forecasting the long-term equilibrium value of the underlying stock. It is the stock value implied from the actual options prices and is taken as a straight and innate measure of the assessment by the options traders about the value of the underlying asset. It is expected that the forecasts based on such implied value are more precise and consistent than the estimates of the same based on other empirically used measures (Cremers et al., 2019). As defined by Black and Scholes (1973), the price of an options contract is a function of the existing value of the asset based on which the value of the option is derived, the variance of the rate of return of the underlying asset, the time remaining for the expiration of the contract, the risk-free rate of interest and the strike price of the contracts. Considering the actual index as the underlying asset, using known and observed parameters, except observed actual index level, the implied index level for call options and put options can be computed by inverting the Black and Scholes (1973) model, based on the assumption that the use of implied index as the value of the underlying index will equate the actual price with its 
theoretical price using the Newton-Raphson framework. The risk-free rate of interest is represented, for the purpose, by the yield on 91 days Treasury Bills.

One of the contributions of this study is the development of time series representations for signifying the options market as a whole. It is done as follows. First, the options contracts are classified into five moneyness categories using the ratios of spot price to strike price and strike price to spot price for the call and the put options, respectively (Bakshi et al., 2000b; Baltussen et al., 2012; Debasish, 2009; Shaikh \& Padhi, 2013). Considering Pan et al. (2014) and Yang et al. (2017), options are classified as Deep-Out-Of-The-Money (DOTM) when the ratio is lower than 0.925 , Out-Of-The-Money (OTM) when the ratio is lower than 0.975 but not less than 0.925, At-The-Money (ATM) when the ratio is lower than 1.025 but not less than 0.975 , In-The-Money (ITM) when the ratio is greater than 1.025 but less than 1.075 , and Deep-In-The-Money (DITM) when the ratio is greater than 1.075. Then, the following filters are applied to arrive at a time-series representation of the options market. From options contracts with different expiration cycles viz. near-month, midmonth, far-month, etc., only near-month options having at least one trade on a trading day are selected. Mukharjee and Mishra (2004) and Dixit et al. (2010) suggested these filters to ensure that only liquid options are being selected. Debasish (2009) pointed out the variability in the implied volatility of the options due to over-liquidity during the maturing week of options. This is avoided by selecting the contracts with a switch to the next expiration cycle, eight days prior to maturity. Srivastava (2003) has also documented the expiration effect of the options contracts. If the options contracts violate arbitrage bounds, it shows that the options are priced against general properties of options pricing models (Bhat \& Arekar, 2016; Jiang \& Tian, 2011). No upper arbitrage boundary violations are seen in the Indian options market. Therefore, the options contracts are filtered for violations of lower arbitrage boundaries. From the multiple contracts remaining after applying the above filters, the one contract with the highest trade volume on the trading day is selected (Muravyev et al., 2013) to represent that day in the concerned moneyness group for the formation of the call and put options time series.

Ensuing to the examination of the normalcy of the data using summary statistics and stationarity of the data using Augmented Dickey-Fuller (ADF) and Phillips Perron (PP) unit root tests, the ability of the options market to mitigate the investment risks implied in the stock market is tested by scrutinising the integration of the options market with the equity market, using the Trace test and the Maximum Eigen-value test in the Johansen cointegration procedure for the relationship given in the Equation (1), following Johansen (1995). 


$$
P_{j, t}-\beta_{0}-\beta_{1} P_{s, t}=\varepsilon_{j, t}
$$

where, $P_{j, t}$ is the value of the implied index for call options or put options as the case may be and $P_{s, t}$ is the value of the actual index for the time $t$.

In order to analyse the strength of its risk reduction ability, the short-term dynamic relationship of the implied index with the actual index is tested using the Vector Error Correction Model (VECM), using Equation (2).

$$
\begin{array}{r}
{\left[\begin{array}{l}
\Delta P_{s, t} \\
\Delta P_{j, t}
\end{array}\right]=\left[\begin{array}{l}
\alpha_{11} \\
\alpha_{21}
\end{array}\right]+\left[\begin{array}{l}
\alpha_{s} \\
\alpha_{j}
\end{array}\right]\left[P_{j, t}-\beta_{0}-\beta_{1} P_{s, t}\right]+} \\
\sum_{i=1}^{k}\left[\begin{array}{ll}
\vartheta_{1, i} & \gamma_{1, i} i \\
\vartheta_{2, i} & \gamma_{2, i}
\end{array}\right]\left[\begin{array}{l}
\Delta P_{s, t-i} \\
\Delta P_{j, t-i}
\end{array}\right]+\left[\begin{array}{l}
u_{s, t} \\
u_{j, t}
\end{array}\right]
\end{array}
$$

Conventionally and conveniently, Ordinary Least Square (OLS) regression is used for estimating the hedge ratio (Ederington, 1979), but its pragmatic consistency is questioned since it does not incorporate possible cointegration and short-run dynamics into the estimation (Lien, 1996). Even though Lien and Tse (1999), Floros and Vougas (2006), and Kenourgios et al. (2008) suggested the use of Vector Autoregression (VAR) and Error Correction (EC) models for the estimation, they are interrogated for their inability to monitor the effects of dynamic nature of the markets. Innovatively, Autoregressive Conditional Heteroskedasticity (ARCH) based timevarying models are used for the estimation of the futures hedge ratio by Cecchetti et al. (1988), Park and Switzer (1995a; 1995b), Lien and Tse (1999), Brooks et al. (2002), Choudhry (2003; 2004), and Floros and Vougas (2006). Zhipang and Shenghong (2017) suggested the use of the Markov Regime Switching Diagonal BEKK-GARCH model for estimating hedge ratios. François et al. (2014) believed that the regime-switching behaviour of the underlying market is to be considered while calculating the optimal hedge ratio. Bai et al. (2019) agree that the hedging performance can be improved by incorporating conditional heteroskedasticity into the estimation. Empirical evidence from the Indian futures market supports the value of GARCH models in estimating hedging gains; such studies include Kumar et al. (2008), Bhaduri and Durai (2008), Gupta and Singh (2009), and Singh (2017), among others.

Therefore, after examining the heteroskedasticity of the data using the ARCHLM test, variances in the daily returns of the options and the equity markets and covariance of both are estimated by the Diagonal BEKK GARCH model, using Equation (3), based on the suggestions in Allen and McAleer (2017). 


$$
\begin{array}{r}
H_{t}=\left(\begin{array}{ll}
H_{s s, t} & H_{s j, t} \\
H_{j s, t} & H_{j j, t}
\end{array}\right)=C^{\prime} C+\sum_{k=1}^{p} \alpha_{k}^{\prime} u_{t-k} u_{t-k}^{\prime} \alpha_{k}+ \\
\sum_{k=1}^{p} \beta_{k}^{\prime} H_{t-k} \beta_{k}
\end{array}
$$

where, $H_{s s, t}$ and $H_{j j, t}$ are the conditional variances of the actual index and the implied indices for the call or the put options as the case may be, respectively, and $H_{s j, t}$ is the conditional covariance between the actual index and the implied index either for the call or for the put options for day $t$.

Finally, the optimal hedge ratio and the gains from hedging at optimal levels are estimated under the minimum variance framework proposed by Ederington (1979). The optimal hedge ratio is the ratio of covariance between the actual index and implied index and variance of the implied index, and it denotes the ratio of options required to hedge equity investments optimally. The hedge gain is the variance reduction caused by the use of options at an optimal ratio. Both are computed using Equations (4) and (5), respectively.

$$
\begin{aligned}
& \text { Optimal Hedge Ratio }(h)=\frac{\operatorname{Cov}\left(\Delta P_{s, t} \Delta P_{j, t}\right)}{\sigma_{\Delta P_{j, t}}^{2}} \\
& \text { Hedging Gain }=\frac{\sigma_{\Delta P_{s, t}}^{2}-\left(\sigma_{\Delta P_{s, t}}^{2}+h_{t-1}^{2} \sigma_{\Delta P_{j, t}}^{2}+2 h_{t-1} \operatorname{Cov}\left(\Delta P_{s, t} \Delta P_{j, t}\right)\right)}{\sigma_{\Delta P_{s, t}}^{2}}
\end{aligned}
$$

where, Cov stands for covariance, $\sigma^{2}$ stands for the variance, and $h$ stands for the optimal hedge ratio as in Equation (4).

\section{Empirical Analysis and Discussion}

\section{Preliminary Analysis}

The bear domination in the Indian equity and equity options markets during the financial crisis of 2008, where the equity market witnessed a steep fall from a level of $6,074.25$ points to $2,885.60$ points within a short period with an average daily drop of $0.27 \%$, demarcates the appropriateness of the period for exploring the risk mitigation behaviour of the options market with particular focus on times of incalculable economic disruption. The price movements in different call and put options markets and their underlying equity segments make it clear that the markets travel together downward during this phase of the financial crisis, symptomatic of having an integration among the market pairs to facilitate the protection of investments from repercussions of such catastrophes (Bakshi et al., 2000b). Considering the nature of the markets during this phase of economic stress, conveyed 
from skewness and excess kurtosis, the data, except that from the DOTM call options segment, are found to have nonconformities to be useful for further econometric evaluations, as they expressed not to have normalcy in them (Alexander \& Nogueira, 2007). The unusual nature of the DOTM calls is due to its reduced speed of falling, resulting from lesser extreme movements within the period (Carr et al., 2002). The entire data have been smoothened to save the results of further analysis from mismatches and errors. One of the general properties of the price series data is its stationarity, which states that that data usually have stimulus from its past (Kim et al., 2009). The results of both the ADF and the PP unit root tests indicate the absence of unit root in the data for all the 10 options segments and the spot market. These results also predispose possible integration among the markets (Holowczak et al., 2006), which is further to be proved for establishing the persistence of the long-run relationship between the options-spot pairs. [The time series plots of the options and spot markets, summary statistics of the data, and results of unit root tests are given as Appendices 1, 2, and 3.]

\section{Does the Equity Options Market Facilitate Risk Reduction During Financial Upheavals?}

Financial stress present in the market during times of economic upheavals may cause the investors to behave differently, to be strong enough to alter the ordinary market characteristics (Maheu et al., 2012). Even when the equity options markets are theoretically expected to be in integration with the equity counterpart (Bakshi et al., 2000b), the risk reduction ability is to be carefully analysed during the periods of apprehensions to prudently learn the potential changes in the market behaviour (Chang et al., 2010), since such behavioural fluctuations may cause intensification of uncertainties in it. It is prudent for the investors to make sure that they remain unaffected from the undesirable effects of spiralling uncertainties by the cautious use of different risk mitigation mechanisms (Brailsford et al., 2001), especially of the options contracts. The vigilant use of the options can be ensured when the investors choose the required level of options contracts for minimising their exposure to a maximum possible extent (Ederington, 1979). Table 1 summarises the results of the Johansen cointegration process. All equity options segments, except the OTM and the DOTM calls and the ITM puts, express a long-run integrating relationship with the underlying equity market by rejecting the null hypothesis that 'the Indian equity options market is hardly ever in integration with the underlying spot market'. When the ATM, the ITM, and the DITM call options demonstrate their usefulness in risk reduction for the prospective investors who wait for achieving maximum benefits from the price falls in the bearish market, the ATM, the OTM, the DOTM, and the DITM put options validate that these segments of the equity options market protect 
the existing investors from the downsides of continuous falls in the value of their assets. The unusual behaviour of the OTM and the DOTM calls and the ITM puts, which is evident from the failure of the markets to reject the null hypothesis, indicates that the pairs of respective options and the underlying spot behave independent of each other, leaving no promises of risk reduction. This may be due to the panic transactions on the part of the investors and the dominance of the speculators who appear to gain benefits from the unprecedented financial ambiguity. The results are supported by the argument that the options market expresses slight efficiency during the financial meltdown (Jain et al., 2013). Even though similar behaviour is expected from the other options segments during the financial crisis period, the results of cointegration make it clear that they are not independent of each other.

Table 1: Integration Between the Options and the Stock Markets

\begin{tabular}{|c|c|c|c|c|c|}
\hline & $\begin{array}{l}\text { No. of } \\
\text { CE(s) }\end{array}$ & Trace & $p$ & $\begin{array}{l}\text { Max- } \\
\text { Eigen }\end{array}$ & $p$ \\
\hline \multicolumn{6}{|c|}{ Panel A: Call Options } \\
\hline \multirow{2}{*}{ ATM } & None $*$ & 21.207 & 0.020 & 18.134 & 0.036 \\
\hline & At most 1 & 3.073 & 0.080 & 3.073 & 0.080 \\
\hline \multirow{2}{*}{ OTM } & None & 14.489 & 0.071 & 12.570 & 0.091 \\
\hline & At most 1 & 1.919 & 0.166 & 1.919 & 0.166 \\
\hline \multirow{2}{*}{ ITM } & None * & 35.129 & 0.000 & 35.053 & 0.000 \\
\hline & At most 1 & 0.076 & 0.783 & 0.076 & 0.783 \\
\hline \multirow{2}{*}{ DOTM } & None & 5.380 & 0.767 & 5.043 & 0.736 \\
\hline & At most 1 & 0.337 & 0.562 & 0.337 & 0.562 \\
\hline \multirow{2}{*}{ DITM } & None $*$ & 47.748 & 0.000 & 47.731 & 0.000 \\
\hline & At most 1 & 0.018 & 0.894 & 0.018 & 0.894 \\
\hline \multicolumn{6}{|c|}{ Panel B: Put Options } \\
\hline \multirow{2}{*}{ ATM } & None $*$ & 17.333 & 0.026 & 17.163 & 0.017 \\
\hline & At most 1 & 0.170 & 0.680 & 0.170 & 0.680 \\
\hline \multirow{2}{*}{ OTM } & None $*$ & 28.340 & 0.000 & 25.507 & 0.001 \\
\hline & At most 1 & 2.833 & 0.092 & 2.833 & 0.092 \\
\hline \multirow{2}{*}{ ITM } & None & 11.027 & 0.210 & 10.924 & 0.158 \\
\hline & At most 1 & 0.103 & 0.748 & 0.103 & 0.748 \\
\hline \multirow{2}{*}{ DOTM } & None $*$ & 25.109 & 0.001 & 23.384 & 0.001 \\
\hline & At most 1 & 1.725 & 0.189 & 1.725 & 0.189 \\
\hline \multirow{2}{*}{ DITM } & None $*$ & 18.427 & 0.018 & 18.031 & 0.012 \\
\hline & At most 1 & 0.396 & 0.529 & 0.396 & 0.529 \\
\hline
\end{tabular}

Note: 'No. of CE(s)' stands for the number of cointegrating equations. 'Trace' and 'Max-Eigen' stand for 'Trace Statistics' and 'Maximum Eigenvalue Statistics' of the tests used to empirically evaluate the presence of a cointegrating equation between the series.

The integration of the options and stock markets alone does not warrant the hedging ability of the options market, as there will be deviations from such 
equilibrium in the short run due to the non-simultaneity of price formation in both the markets. At this juncture, an analysis of the short-run dynamics between the integrated market pairs becomes essential, as the long-run co-movement is possible only when there is the reinstatement of the simultaneity among the markets. Table 2 provides the results of the VECM. Since the intention of the study is to examine how effectively the deviations in the long-run integration are corrected in the short-run, only the error correction coefficient is reported in the table, and the coefficients of each of the 'difference terms' are excluded. When the error correction terms are negative, it indicates that there is a tendency for the concerned market to lead in the re-adjustment process, but this reinstating tendency becomes considerable only when the coefficients are significant. Since the error correction term denotes the percentage of error correction that takes place during one day (as the data used is of daily frequency), the number of days taken by the respective market component is identifiable from dividing one (1) by the respective error correction term, considering the same models. In comparison with the ATM call and the ATM, the DOTM and the DITM put options markets, the Indian equity market expresses to have a minimal tendency to lead in the process of regaining the equilibrium among the markets, but it fails to initiate any significant rebalancing. In cases of options markets having integration with the stock market, all the options segments show statistically significant readjusting dynamism towards the equilibrium state with the stock market. The ATM, the ITM, and the DITM call options markets ensure that the prospective investors can rely upon its integration with the equity market, as they consume only 3.0, 3.9, and 3.6 days to regain the equilibrium, respectively. The ATM, the OTM, the DOTM, and the DITM put options markets are also dependable as they need only $3.3,3.4,2.2$, and 1.9 days, respectively, to regain the equilibrium with the underlying equity market.

Table 2: Short-Run Dynamics Between the Stock and the Options Market

\begin{tabular}{lcccccc}
\hline & \multicolumn{3}{c}{ Spot } & & \multicolumn{3}{c}{ Options } \\
\hline & $\begin{array}{c}\text { EC } \\
\text { Coeff. }\end{array}$ & $\boldsymbol{p}$ & $\begin{array}{c}\text { No. of } \\
\text { Days }\end{array}$ & $\begin{array}{c}\text { EC } \\
\text { Coeff. }\end{array}$ & $\boldsymbol{p}$ & $\begin{array}{c}\text { No. of } \\
\text { Days }\end{array}$ \\
\hline Panel A: Call Options & & & & & & \\
\hline ATM & -0.111 & 0.488 & - & -0.332 & 0.012 & 3.0 \\
ITM & 0.175 & 0.119 & - & -0.253 & 0.007 & 3.9 \\
DITM & 0.153 & 0.015 & - & -0.278 & 0.000 & 3.6 \\
\hline Panel B: Put Options & & & & & & \\
\hline ATM & -0.038 & 0.755 & - & -0.301 & 0.036 & 3.3 \\
OTM & 0.080 & 0.442 & - & -0.291 & 0.022 & 3.4 \\
DOTM & -0.091 & 0.308 & - & -0.462 & 0.000 & 2.2 \\
DITM & -0.273 & 0.209 & - & -0.521 & 0.039 & 1.9 \\
\hline
\end{tabular}

Note: 'EC Coeff.' stands for the coefficient of the error correction term in the VECM. 
Even in the absence of integration, the markets may have short-run dynamic relationships. But such a relationship is not considered in the study for the OTM and the DOTM calls and the ITM put options markets. Even though the options are shortrun in nature and the hedging using the options is also a short-run exercise, for the purpose of computing the hedge ratio and hedging effectiveness, we consider only those market pairs that have enduring long-lasting co-moving relationships among them, as the dependability of a market hails from its persisting behaviour, rather than short term trends.

\section{The Extent of Risk Reduction and Effective Gains from Hedging}

Since risks are dependent on unstipulated circumstances, an optimal hedge ratio, in the minimum variance structure, expresses the number of options that can mitigate the risks implied in the underlying investments to a maximum possible extent (Ederington, 1979). Since the OTM call, the DOTM call, and the ITM put options are completely independent with the underlying spot market in the long-run, and they are unable to facilitate persevering effective hedging, there is no significance in estimating the hedge ratio. The optimal hedge ratios and the gains resulting from such hedges for each of the market pairs showing hedging ability are given in Table 3 . [The results of the ARCH LM test and the D-BEKK GARCH estimation are given in Appendices 4 and 5.]

Table 3: Optimal Hedge Ratio and Hedging Gains

\begin{tabular}{llcc}
\hline Option Type & Moneyness & Optimal Hedge Ratio & Hedging Gain \\
\hline \multirow{4}{*}{ Call Options } & ATM & 1.09 & $91.12 \%$ \\
& ITM & 0.93 & $81.12 \%$ \\
& DITM & 0.73 & $53.51 \%$ \\
\hline \multirow{5}{*}{ Put Options } & ATM & 0.75 & $86.91 \%$ \\
& OTM & 0.65 & $70.51 \%$ \\
& DOTM & 0.46 & $47.27 \%$ \\
& DITM & 0.85 & $92.37 \%$ \\
\hline
\end{tabular}

Efficient use of the options market can be helpful for the investors with long positions when an incessant downward drive formed by continuous selling pressure from the market tends to captivate their past earnings as well as invested capital. Put options can save them from the damages of huge falls in the underlying market, and further use of call options may allow them to have assured benefits of synthetic short sales. The prospective investors can use the call options to predetermine a price level at which they desire to long in the underlying asset. But, in both situations, the optimal level of risk mitigation is to be considered by the market participants. 
Generally, investment preferences are subject to the willingness of the investors with ample availability of financial resources to expend the same according to their inclinations on uncertainties. The effectiveness of a portfolio comprising of spots and derivatives, created for risk dilution purposes, varies according to the risk perception of the investors (Chuang et al., 2015). Moreover, a selection on the type of options for effecting the hedge is contingent upon the trade-off between the risk perception of the investors and their willingness to have initial financial outlay (Ederington, 1979; Bond \& Thompson, 1985). The ATM options are likely to deliver accurate expectancy on the actual value of the underlying asset (Srivastava \& Shastri, 2020) with relatively lesser prices compared with other moneyness levels due to the lower level of implied volatility (Bhat \& Arekar, 2016) and they can be selected by those who neither expect further massive changes in the existing value of the underlying asset nor wish to pay more for securing their interests. If they intend to secure probable purchases of equity, holding call options at a ratio of 1.09 , i.e., slightly higher than the naïve position, may provide an assured risk reduction up to $91.12 \%$. When they desire to protect their existing cash outlay in the equity from further losses, the use of put options at a ratio of 0.75 is expected to offer a decline in the expected variance up to $86.91 \%$. The call options are in-the-money when their strike prices are lower than the current market price, giving an upright opportunity for the options to be exercisable but purchasable only at a higher premium due to the level of intrinsic values. Prospective investors desirous of purchasing the underlying asset in the near future at a profitable level without having enhanced initial monetary outlay can use ITM calls, and a portfolio of equity and calls at a ratio of 0.93 for a single unit of equity can provide a reduction of variance up to $81.12 \%$. But investors who wish to buy equity at the lowest possible price irrespective of the cost aspect can choose a combination of equity and DITM calls at a ratio of 0.73 , expecting a hedging gain of $53.51 \%$. Put options are out-of-the-money when their exercise prices are lower than the spot values of the underlying asset and are available at lesser premiums due to its non-exercisability. Investors who do not expect further fall in the prices of the underlying asset can opt for OTM put options, and its use with the equity assets at a ratio of 0.65 is expected to reduce the risks up to $70.51 \%$. If they opt for the DOTM puts to be the risk mitigation tool, its use with the spot at a ratio of 0.46 will provide a variance reduction of $47.27 \%$ to them. Investors who are eager to earn maximum profits from the already existing equity assets, compromising the cost aspect of buying options for the same, can reduce their risks up to a significant level of $92.37 \%$ by the use of DITM put options at a ratio of 0.85 . The results are consistent with the findings of Hull and White (2017), who found that both the calls and puts are efficient 
in hedging but do not show significant differences in their effectiveness when the market faces upheavals. With a special focus on a bearish trend that may prevail in the stock market, the existing investors in equity can use either put options or a combination of puts and calls to secure their investments and also to book the required level of profits.

\section{Conclusion}

The current study is designed to identify the suitability of the Indian equity options market for facilitating the protection of existing as well as prospective investors from undesirable price movements in the underlying market during periods of financial stress and to estimate an optimal level of options to be used for mitigating the uncertainties to the maximum probable extent, following the minimum variance approach. The lack of integration of the OTM call and the DOTM call and the ITM put options with the equity market denotes the absence of hedging ability in these market segments. However, all other segments express to have significant ability to shield the equity investments throughout the period under consideration, even in the presence of short-run deviations from their integration with the spot market. Further, hedge portfolios developed by incorporating any one of the options segments with the underlying equity have a risk reduction ranging from $47 \%$ to $91 \%$. When compared with the reported effective risk reduction initiated from the Indian futures market (Gupta \& Singh, 2009; Jose \& Lazar, 2012; Singh, 2017), the results of the present study do not disprove the findings of Chang and Shankar (1986) and Lien and Tse (2001) that the futures contracts outperform the options in terms of hedging effectiveness. But the inherent disadvantage of the futures that it fails to assist the hedger in benefiting from favourable market movements leads to a suggestion that those investors who are desirous of mitigating the risk exposure to a great extent without any compromises in the benefits can opt for combinations of futures and options altogether to have a better hedging portfolio. Even though Lee and Nayar (1993), Kyriacou and Sarno (1999), Ryu (2015), Ryu and Yang (2017), and Ahn et al. (2018) support the joint use of options and futures for a better risk mitigation in their common underlying spot market, the benefits from such joint explorations are yet to be empirically evaluated.

\section{Declaration of Conflicting Interests}

The authors declared no potential conflicts of interest with respect to the research, authorship, and publication of this article. 


\section{References}

Abhyankar, A. H. (1995). Return and volatility dynamics in FT-SE 100 stock index and stock index futures markets. The Journal of Finance, 15(4), 457-488. https://doi.org/10.1002/fut.3990150405

Ackert, L. F., \& Tian, Y. S. (2001). Efficiency in index options markets and trading in stock baskets. Journal of Banking and Finance, 25(9), 1607-1634. https://doi.org/10.1016/S0378-4266(00)00145-X

Aggarwal, N., \& Gupta, M. (2009). Empirical evidence on the efficiency of index options market in India. Asia-Pacific Business Review, 5(3), 106-116. https://doi.org/10.1177/097324700900500311

Ahn, K., Bi, Y., \& Sohn, S. (2018). Price discovery among SSE 50 Index-based spot, futures and options markets. Journal of Futures Market, 39(2), 01-22. https://doi.org/10.1002/fut.21970

Alexander, C., Kaeck, A., \& Nogueira, L. M. (2009). Model risk adjusted hedge ratio. The Journal of Futures Markets, 26(11), 1021-1049. https://doi.org/10.1002/fut.20406

Alexander, C., \& Nogueira, L. M. (2007). Model free hedge ratios and scale invariant model. Journal of Banking and Finance, 31(6), 1839-1861. https://doi.org/10.1016/j.jbankfin.2006.11.011

Alexander, C., Prokopczuk, M., \& Sumawong, A. (2013). The (de)merits of minimum-variance hedging: Application to the crack spread. Energy Economics, 36, 698-707. https://doi.org/10.1016/j.eneco.2012.11.016

Allen, D. E., \& McAleer, M. J. (2017). Theoretical and empirical differences between Diagonal and Full BEKK for risk management (Tinbergen Institute Discussion Paper No. 17-069/III). Tinbergen Institute. https://www.tinbergen.nl/discussion-paper/3153/17-069-iii-theoretical-andempirical-di-fferences-between-diagonal-and-full-bekk-for-risk-management

An, Y., \& Suo, W. (2009). An empirical comparison of option pricing models in hedging exotic options. Financial Management, 38(4), 889-914. https://www.jstor.org/stable/40388698

Bagchi, D. (2012). Cross-sectional analysis of emerging market volatility index (India VIX) with portfolio returns. International Journal of Emerging Markets, 7(4), 383-396. https://doi.org/10.1108/17468801211264306

Bai, Y., Pan, Z., \& Liu, L. (2019). Improving futures hedging performance using option information: Evidence from the S\&P 500 index. Finance Research Letters, 28, 112-117. https://doi.org/10.1016/j.frl.2018.04.014 
Bakshi, G., Cao, C., \& Chen, Z. (1997). Empirical performance of alternative option pricing models. The Journal of Finance, 52(5), 2003-2049.

https://doi.org/10.2307/2329472

Bakshi, G., Cao, C., \& Chen, Z. (2000a). Pricing and hedging long-term options. Journal of Econometrics, 94(1-2), 277-318. https://doi.org/10.1016/S03044076(99)00023-8

Bakshi, G., Cao, C., \& Chen, Z. (2000b). Do call prices and underlying stock always move in the same direction? The Review of Financial Studies, 13(3), 549-584. https://www.jstor.org/stable/2645996?seq=1

Baltussen, G., Grient, B. V., Groot, W. D., Hennink, E., \& Zhou, W. (2012). Exploiting option information in the equity market. Financial Analysts Journal, 68(4), 56-72. https://doi.org/10.2469/faj.v68.n4.1

Bhaduri, S. N., \& Durai, S. R. (2008). Optimal hedge ratio and hedging effectiveness of stock index futures; Evidence from India. Macroeconomics and Finance in Emerging Market Economies, 1(1), 121-134. https://doi.org/10.1080/17520840701859856

Bhat, A., \& Arekar, K. (2016). Empirical performance of Black - Scholes and GARCH option pricing models during turbulent times: The Indian evidence. International Journal of Economics and Finance, 8(3), 123-136. http://ccsenet.org/journal/index.php/ijef/article/view/55847

Bhattacharya, M. (1987). Price changes of related securities: The case of call options and stocks. Journal of Financial and Quantitative Analysis, 22(1), 115. https://doi.org/10.2307/2330866

Black, F., \& Scholes, M. (1973). The pricing of options and corporate liabilities. Journal of Political Economy, 81(3), 637-654. https://www.jstor.org/stable/1831029?seq=1

Bond, G. E., \& Thompson, S. R. (1985). Risk aversion and the recommended hedging ratio. American Journal of Agricultural Economics, 67(4), 870872.https://doi.org/10.2307/1241828

Booth, G. G., Tse, Y., \& So, R. W. (1999). Price discovery in the German equity index derivatives markets. The Journal of Futures Market, 19(6), 619-643. https://doi.org/10.1002/(SICI)1096-9934(199909)19:6<619::AIDFUT1>3.0.CO;2-M

Brailsford, T., Corrigan, K., \& Heaney, R. (2001). A comparison of measures of hedging effectiveness: A case study using the Australian All Ordinaries Share Price Index futures contract. Journal of Multinational Financial Management, 11(4-5), 465-481. https://doi.org/10.1016/S1042-444X(01)00036-6 
Brooks, C., Henry, Ó. T., \& Persand, G. (2002). The effect of asymmetries on optimal hedge ratios. The Journal of Business, 75(2), 333-352.

https://doi.org/10.1086/338484

Buraschi, A., \& Jackwerth, J. (2001). The price of a smile: Hedging and spanning in options markets. The Review of Financial Studies, 14(2), 495-527. https://www.jstor.org/stable/2696749?seq=1

Butterworth, D., \& Holmes, P. (2001). The hedging effectiveness of stock index futures: Evidence for the FTSE-100 and FTSE-mid250 indexes traded in the UK. Applied Financial Economics, 11(1), 27-68. https://doi.org/10.1080/09603100150210264

Cao, C., \& Huang, J.-Z. (2007). Determinants of S\&P 500 Index Options. Review of Derivatives Research, 10, 01-38. https://doi.org/10.1007/s11147-007-9015-5

Carr, P., Geman, H., Madan, D. B., \& Yor, M. (2002). The fine structure of asset returns: An empirical investigation. Journal of Business, 75(2), 305-332. https://doi.org/10.1086/338705

Cecchetti, S. G., Cumby, R. E., \& Figlwiski, S. (1988). Estimation of optimal futures hedge. The Review of Economics and Statistics, 70(4), 623-630. https://doi.org/10.2307/1935825

Chakravarthy, S., Gulen, H., \& Mayhew, S. (2004). Informed trading in stock and option market. The Journal of Finance, 59(3), 1235-1257. https://www.jstor.org/stable/3694735?seq=1

Chan, K., Chung, Y. P., \& Fong, W.-M. (2002). The informational role of option volume. The Review of Financial Studies, 15(4), 1049-1075. https://www.jstor.org/stable/1262691?seq=1

Chan, K., Chung, Y. P., \& Johnson, H. (1993). Why option prices lag stock prices: A trading based explanation. The Journal of Finance, 48(5), 1957-1967. https://doi.org/10.1111/j.1540-6261.1993.tb05136.X

Chan, K. C., Chang, Y., \& Lung, P. P. (2009). Informed trading under different market conditions and moneyness: Evidence from TXO options. Pacific-Basin Finance Journal, 17(2), 189-208. https://doi.org/10.1016/j.pacfin.2008.02.003

Chang, C.-Y., Lai, J.-Y., \& Chuang, I.-Y. (2010). Futures hedging effectiveness under the segmentation of bear/bull energy markets. Energy Economics, 32(2), 442-449. https://doi.org/10.1016/j.eneco.2009.09.012

Chang, J. S., \& Shankar, L. (1986). Hedging effectiveness of currency options and currency futures. The Journal of Futures Markets, 6(2), 289-305. https://doi.org/10.1002/fut.3990060210 
Chen, S.-S., Lee, C.-F., \& Shrestha, K. (2003). Futures hedge ratios: A review. The Quarterly Review of Economics and Finance, 43(3), 433-465. https://doi.org/10.1016/S1062-9769(02)00191-6

Chen, S.-S., Lee, C.-F., \& Shrestha, K. (2008). Do the pure martingale and joint normality hypotheses hold for futures contracts? Implications for the optimal hedge ratios. The Quarterly Review of Economics and Finance, 48(1), 153-174. https://doi.org/10.1016/j.qref.2005.10.002

Chiang, R., \& Fong, W.-M. (2001). Relative informational efficiency of cash, futures, and options markets: The case of an emerging market. Journal of Banking and Finance, 25(2), 355-375. https://doi.org/10.1016/S03784266(99)00127-2

Choudhry, T. (2003). Short-run deviations and optimal hedge ratio: Evidence from stock futures. Journal of Multinational Financial Management, 13(2), 171-192. https://doi.org/10.1016/S1042-444X(02)00042-7

Choudhry, T. (2004). The hedging effectiveness of constant and time-varying hedge ratios using three Pacific basin stock futures. International Review of Economics and Finance, 13(4), 371-385. https://doi.org/10.1016/j.iref.2003.04.002

Chuang, C.-C., Wang, Y.-H., Yeh, T.-J., \& Chuang, S.-L. (2015). Hedging effectiveness of the hedged portfolio: The expected utility maximization subject to the value-at-risk approach. Applied Economics, 47(20), 2040-2052. https://www.tandfonline.com/doi/abs/10.1080/00036846.2014.1000528

Conover, C. M., \& Peterson, D. R. (1999). The lead-lag relationship between the option and stock markets prior to substantial earnings surprises and the effect of security regulation. Journal of Financial and Strategic Decisions, 12(1), 41-52.

Cremers, M., Goyenko, R., Schultz, P., \& Szaura, S. (2019). Informed trading of options, option expiration risk, and stock return predictability. https://dx.doi.org/10.2139/ssrn.3347194

Debasish, S. S. (2009). An econometric analysis of the lead-lag relationship between India's NSE Nifty and its derivative contracts. The Journal of Risk Finance, 10(4), 350-364. https://doi.org/10.1108/15265940910980650

DeMaskey, A. L. (1995). A comparison of the effectiveness of currency futures and currency options in the context of foreign exchange risk management. Managerial Finance, 21(4), 40-51. https://doi.org/10.1108/eb018511

Dixit, A., Yadav, S. S., \& Jain, P. (2010). Informational efficiency of implied volatilities of S\&P CNX Nifty Index Options: A study in Indian securities market. Journal of Advances in Management Research, 7(1), 32-57. https://doi.org/10.1108/09727981011042847 
Du, B., \& Fung, S. (2018). Directional information effects of options trading: Evidence from the banking industry. Journal of International Financial Markets, Institutions \& Money, 56, 149-168. https://doi.org/10.1016/j.intfin.2018.02.009

Dumas, B., Fleming, J., \& Whaley, R. E. (1998). Implied volatility functions: Empirical tests. The Journal of Finance, 53(6), 2059-2106. https://www.jstor.org/stable/117461?seq=1

Easley, D., O'Hara, M., \& Sreenivas, P. (1998). Option volume and stock prices: Evidence on where unformed traders trade. The Journal of Finance, 53(2), 431465. https://www.jstor.org/stable/117358?seq=1

Ederington, L. H. (1979). The hedging performance of the new futures market. The Journal of Finance, 34(1), 157-170. https://doi.org/10.1111/j.15406261.1979.tb02077.x

Evnine, J., \& Rudd, A. (1984). Index options: The early evidence. The Journal of Finance, 40(3), 743-756. https://doi.org/10.1111/j.1540-6261.1985.tb04998.x

Fama, E. (1970). Efficient capital markets: A review of theory and empirical work. The Journal of Finance, 25(2), 383-417. https://doi.org/10.2307/2325486

Fleming, J., Ostdick, B., \& Whaley, R. E. (1996). Trading costs and the relative rates of price discovery in stock, futures and option markets. The Journal of Futures Market, 16(4), 353-387. https://doi.org/10.1002/(SICI)10969934(199606)16:4<353::AID-FUT1>3.0.CO;2-H

Floros, C., \& Vougas, D. V. (2006). Hedging effectiveness in Greek stock index futures market. Applied Financial Economics, 14(15), 1125-1136. https://doi.org/10.1080/09603100412331297702

François, P., Gauthier, G., \& Godin, F. (2014). Optimal hedging when the underlying asset follows a regime-switching Markov process. European Journal of Operational Research, 237(1), 312-322. https://doi.org/10.1016/j.ejor.2014.01.034

Gupta, K., \& Singh, B. (2009). Estimating the optimal hedge ratio in the Indian equity futures market. Journal of Financial Risk Management, 6(3\&4), 38-98.

Harvey, C. R., \& Whaley, R. E. (1992). Market volatility prediction and the efficiency of the S\&P 100 index option market. Journal of Financial Economics, 31(1), 42-73. https://doi.org/10.1016/0304-405X(92)90011-L

Hentze, S., \& Seiler, M. J. (2000). An examination of the lead/lag relationship between the option market and the stock market: Where do we stand? Quarterly Journal of Business and Economics, 39(1), 35-48. https://www.jstor.org/stable/40473282?seq=1 
Holowczak, R., Simaan, Y. E., \& Wu, L. (2006). Price discovery in the US stock and stock option markets: A portfolio approach. Review of Derivatives Research, 9, 37-65. https://doi.org/10.1007/s11147-006-9004-0

Hull, J., \& White, A. (2017). Optimal delta hedging for options. Journal of Banking and Finance, 82, 180-190. https://doi.org/10.1016/j.jbankfin.2017.05.006

Jain, P., Vyas, V., \& Roy, A. (2013). A study on weak form of market efficiency during the period of global financial crisis in the form of random walk on Indian capital market. Journal of Advances in Management Research, 10(1), 122-138. https://doi.org/10.1108/09727981311327802

Jiang, G. J., \& Tian, Y. S. (2011). A random walk down the options market. The Journal of Futures Market, 32(6), 505-535. https://doi.org/10.1002/fut.20528

Johansen, S. (1995). A statistical analysis of cointegration for I(2) variables. Econometric Theory, 25-59. https://www.jstor.org/stable/3532929?seq=1

Jose, B., \& Lazar, D. (2012). Should investor invest in both future and spot market? An analysis through optimal hedge ratio. Asian Business Review, 1(1)21-29. https://doi.org/10.18034/abr.v1i1.140

Kamara, A., \& Miller, T. W. (1995). Daily and intradaily test of European put-call parity. The Journal of Financial and Quantitative Analysis, 30(4), 519-539. https://doi.org/10.2307/2331275

Kamara, A., \& Siegel, A. F. (1987). Optimal hedging in futures markets with multiple delivery specifications. The Journal of Finance, 42(4), 1007-1021. https://doi.org/10.1111/j.1540-6261.1987.tb03924.x

Kang, J., \& Park, H.-J. (2014). How informed investors take advantage of negative information in options and stock market. The Journal of Futures Market, 34(6), 516-547. https://doi.org/10.1002/fut.21651

Kenourgios, D., Samitas, A., \& Drosos, P. (2008). Hedge ratio estimation and hedging effectiveness: the case of the S\&P 500 stock index futures contract. International Journal of Risk Assessment and Management, 9(1-2), 121-134. http://www.inderscience.com/offer.php?id=19316 (Check this please)

Kim, S., Kim, I. J., \& Nam, S. O. (2009). The lead-lag relationship between stock index options and the stock index market: Model, moneyness and news. International Journal of Managerial Finance, 5(3), 311-332. https://doi.org/10.1108/17439130910969738

Kim, T. S., Park, Y. J., \& Noh, J. (2013). The linkage between the options and credit default swap markets during the subprime mortgage crisis. The Journal of Futures Markets, 33(6), 518-554. https://doi.org/10.1002/fut.21595 
Kumar, A., \& Raman, T. V. (2017). Testing market efficiency using lower boundary conditions of Indian options market. International Journal of Applied Business and Economic Research, 15(1) 55-65.

Kumar, B., Singh, P., \& Pandey, A. (2008). Hedging effectiveness of constant and time varying hedge ratio in Indian stock and commodity futures markets. https://dx.doi.org/10.2139/ssrn.1206555

Kumar, R., Sarin, A., \& Shastri, K. (1995). The impact of index options on the underlying stock: The evidence from the listing of Nikkei Stock Average Options. Pacific-Basin Finance Journal, 3(2-3), 303-317. https://doi.org/10.1016/0927-538X(95)00006-7

Kyriacou, K., \& Sarno, L. (1999). The temporal relationship between derivatives trading and spot market volatility in the U.K.: Empirical analysis and Monte Carlo evidence. The Journal of Futures Markets, 19(3), 245-270. https://doi.org/10.1002/(SICI)1096-9934(199905)19:3<245::AIDFUT1>3.0.CO;2-J

Lee, J. H., \& Nayar, N. (1993). A transactions data analysis of arbitrage between index options and index futures. The Journal of Futures Markets, 13(8), 889902. https://doi.org/10.1002/fut.3990130806

Lien, D., \& Tse, Y. K. (1999). Fractional cointegration and futures hedging. The Journal of Futures Markets, 19(4), 457-474. https://doi.org/10.1002/(SICI)1096-9934(199906)19:4<457::AIDFUT4>3.0.CO;2-U

Lien, D., \& Tse, Y. K. (2001). Hedging downside risk: Futures vs. options. International Review of Economics and Finance, 10(2), 159-169. https://doi.org/10.1016/S1059-0560(00)00074-5

Lien, D.-H. D. (1996). The effect of the cointegration relationship on futures hedging: A note. The Journal of Futures Markets, 16(7), 773-780. https://doi.org/10.1002/(SICI)1096-9934(199610)16:7<773::AIDFUT3>3.0.CO;2-L

Maheu, J. M., McCurdy, T. H., \& Song, Y. (2012). Components of bull and bear markets: Bull corrections and bear rallies. Journal of Business \& Economic Statistics, 30(3), 391-403. https://doi.org/10.1080/07350015.2012.680412

Manaster, S., \& Rendleman, R. J. (1982). Option prices as predictors of equilibrium stock prices. Journal of Finance, 37(4), 1043-1057. https://doi.org/10.1111/j.1540-6261.1982.tb03597.x 
Mazouz, K., Wu, Y., \& Yin, S. (2015). Trading activity in options and stock around price-sensitive news announcements. Journal of Futures Market, 35(12), 11731194. https://doi.org/10.1002/fut.21691

Mittnik, S., \& Rieken, S. (2000). Put-call parity and the informational efficiency of the German DAX-index options market. International Review of Financial Analysis, 9(3), 259-279. https://doi.org/10.1016/S1057-5219(99)00024-1

Mohanti, D., \& Priyan, P. K. (2014). An empirical test of market efficiency of Indian index options market using the Black-Scholes Model and dynamic hedging strategy. Paradigm, 18(2), 221-237.

https://doi.org/10.1177/0971890714558709

Mukharjee, K. N., \& Mishra, R. (2004). Impact of open interest and trading volume in option market on underlying cash market: Empirical evidence from Indian equity options market.

https://papers.ssrn.com/sol3/papers.cfm?abstract_id=695745

Muravyev, D., Pearson, N. D., \& Broussard, J. P. (2013). Is there price discovery in equity options? Journal of Financial Economics, 107(2), 259-283.

https://doi.org/10.1016/j.jfineco.2012.09.003

Mutum, K., \& Das, A. K. (2019). Lower boundary conditions and pricing efficiency testing of Indian index options market: Empirical evidence from Nifty 50 Index. Indian Journal of Finance, 13(3), 26-38.

http://www.indianjournaloffinance.co.in/index.php/IJF/article/view/142266

Pan, G.-G., Shiu, Y.-M., \& Wu, T.-C. (2014). The effects of stochastic volatility and demand pressure on the monotonicity property violations. The Journal of Derivatives, 22(1), 90-102. https://jod.pm-research.com/content/22/1/90

Park, T. H., \& Switzer, L. N. (1995a). Time varying distributions and the optimal hedge ratios for stock index futures. Applied Financial Economics, 5(3), 131137. https://doi.org/10.1080/758523000a

Park, T. H., \& Switzer, L. N. (1995b). Bivariate GARCH estimation of the optimal hedge ratios for stock index futures: A note. The Journal of Futures Market, 15(1), 61-67. https://doi.org/10.1002/fut.3990150106

Rao, S. N., \& Thakur, S. K. (2008). Optimal hedge ratio and hedge efficiency: An empirical investigation of hedging in Indian derivatives market. Society of Actuaries, Monograph Publication, 01-27.

Ren, F., Ji, S.-D., Cai, M.-L., Li, S.-P., \& Jiang, X.-F. (2019). Dynamic lead-lag relationship between stock indices and their derivatives: A comparative study between Chinese mainland, Hong Kong and US stock markets. Physica A:

Statistical Mechanics and its Applications, 513, 709-723.

https://doi.org/10.1016/j.physa.2018.08.117 
Ross, S. A. (1976). Options and efficiency. The Quarterly Journal of Economics, 90(1), 75-89. https://doi.org/10.2307/1886087

Ryu, D. (2015). The information content of trades: An analysis of KOSPI 200 index derivatives. The Journal of Futures Market, 35(3), 201-221. https://doi.org/10.1002/fut.21637

Ryu, D. (2016). Considering all microstructure effects: The extension of a trade indicator model. Economics Letters, 146, 107-110. https://doi.org/10.1016/j.econlet.2016.07.025

Ryu, D., \& Yang, H. (2017). Price disagreements and adjustments in index derivatives markets. Economics Letters, 151, 104-106. https://doi.org/10.1016/j.econlet.2016.12.016

Shaikh, I., \& Padhi, P. (2013). On the linkages among ex-ante and ex-post volatility: Evidence from NSE Options Market (India). Global Business Review, 14(3), 487-505. https://doi.org/10.1177/0972150913496866

Shaikh, I., \& Padhi, P. (2015). On the relationship of ex-ante and ex-post volatility: A sub-period analysis of S\&P CNX Nifty Index Options. Journal of Emerging Market Finance, 14(2), 140-175. https://doi.org/10.1177/0972652715584266

Singh, G. (2017). Estimating optimal hedge ratio and hedging effectiveness in the NSE index futures. Jindal Journal of Business Research, 6(2), 108-131. https://doi.org/10.1177/2278682117715358

Srivastava, A., \& Shastri, M. (2020). A study of Black-Scholes Model's applicability in Indian capital markets. Paradigm, 24(1), 73-92. https://doi.org/10.1177\%2F0971890720914102

Srivastava, S. (2003). Informational content of trading volume on open interest: An empirical analysis of stock option (NSE Research Initiative Working Paper No. 29). https://dx.doi.org/10.2139/ssrn.606121

Vipul. (2008). Cross-market efficiency in the Indian derivative market: A test of put-call parity. The Journal of Futures Markets, 28(9), 889-910. https://doi.org/10.1002/fut.20325

Yang, H., Lee, J., \& Ryu, D. (2017). Market depth, domestic investors and price monotonicity violations. Applied Economics Letters, 25(10), 688-692. https://doi.org/10.1080/13504851.2017.1355539

Zhang, H., \& Watada, J. (2019). An analysis of the arbitrage efficiency of the Chinese SSE 50ETF Options Market. International Review of Economics and Finance, 59, 474-489. https://doi.org/10.1016/j.iref.2018.10.011

Zhipang, Y., \& Shenghong, L. (2017). Hedge ratio on Markov Regime Switching Diagonal Bekk GARCH Model. Finance Research Letters, 24, 49-55. https://doi.org/10.1016/j.frl.2017.06.015 


\section{Appendix 1: Movements of the Equity and Options Markets}

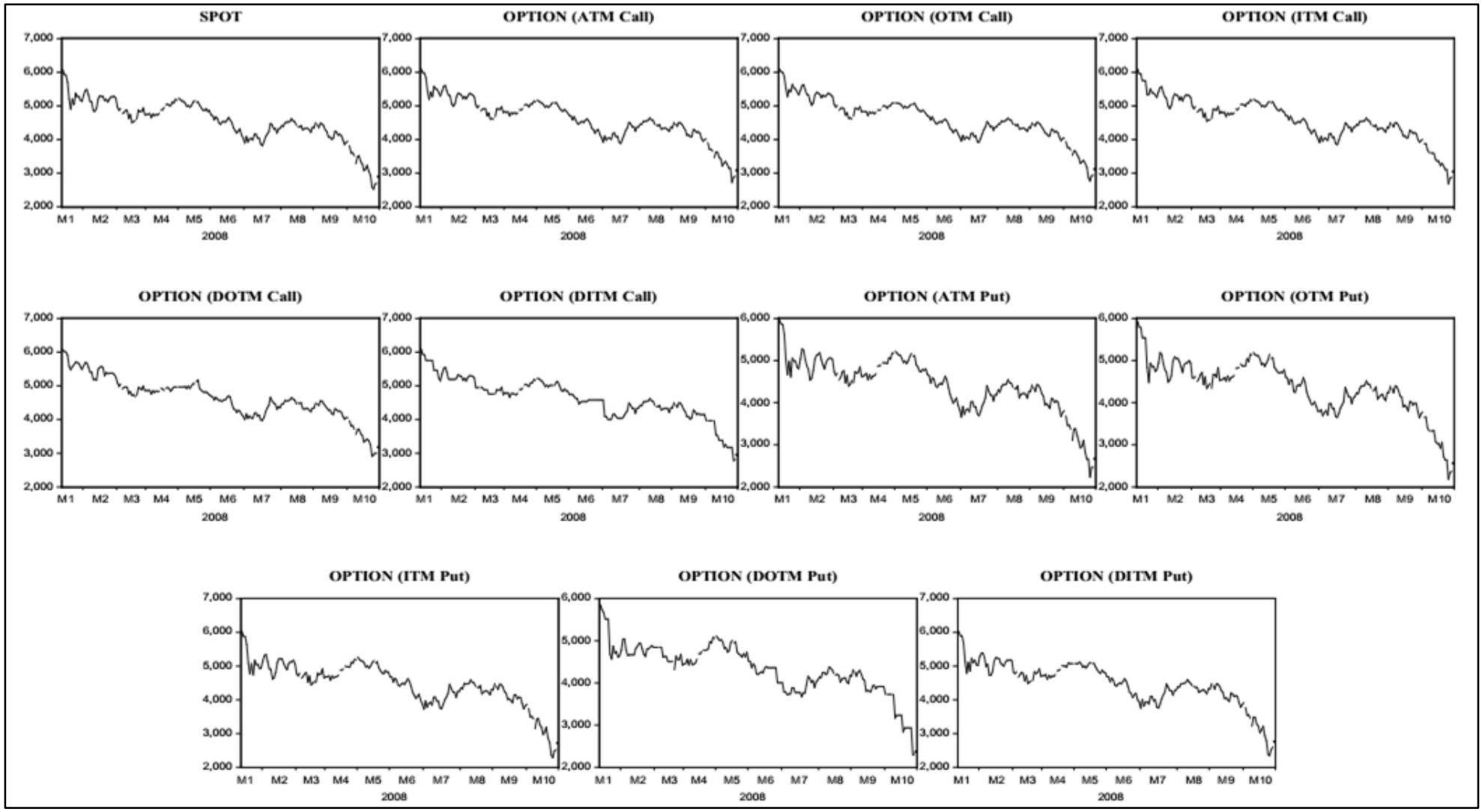

Note: 'SPOT' stands for the 'actual index' and 'OPTION' stands for 'implied index'. The terms given within the brackets denote the options market segment under consideration. 
Appendix 2: Summary Statistics

\begin{tabular}{lcccccc}
\hline & Mean & $\begin{array}{c}\text { Std. } \\
\text { Dev. }\end{array}$ & Skewness & Kurtosis & $\begin{array}{c}\text { Jarque- } \\
\text { Bera }\end{array}$ & $p$ \\
\hline Panel A: Actual index & & & & & & \\
\hline Spot & 4535.0 & 632.3 & -0.77 & 3.96 & 27.0 & 0.00 \\
\hline \multicolumn{1}{l}{ Panel B: Implied index for Call options } & & & & \\
\hline ATM & 4591.7 & 611.2 & -0.47 & 3.44 & 8.8 & 0.01 \\
OTM & 4600.7 & 609.3 & -0.43 & 3.51 & 8.3 & 0.02 \\
ITM & 4581.5 & 618.2 & -0.47 & 3.43 & 8.8 & 0.01 \\
DOTM & 4633.9 & 612.3 & -0.29 & 3.34 & 3.8 & 0.15 \\
DITM & 4617.7 & 603.7 & -0.50 & 3.64 & 11.6 & 0.00 \\
\hline Panel C: Implied index for Put options & & & & \\
\hline ATM & 4402.9 & 643.1 & -0.84 & 4.15 & 34.1 & 0.00 \\
OTM & 4358.8 & 644.5 & -0.81 & 4.25 & 34.0 & 0.00 \\
ITM & 4450.5 & 647.4 & -0.89 & 4.29 & 39.5 & 0.00 \\
DOTM & 4323.3 & 593.9 & -0.71 & 4.41 & 32.8 & 0.00 \\
DITM & 4475.8 & 639.1 & -0.88 & 4.31 & 39.2 & 0.00 \\
\hline
\end{tabular}

Appendix 3: Stationarity of the Data

\begin{tabular}{|c|c|c|c|c|c|c|c|c|}
\hline & \multicolumn{4}{|c|}{ ADF } & \multicolumn{4}{|c|}{$\mathbf{P P}$} \\
\hline & \multicolumn{2}{|c|}{ Level } & \multicolumn{2}{|c|}{ Difference } & \multicolumn{2}{|c|}{ Level } & \multicolumn{2}{|c|}{ Difference } \\
\hline & $\tau$ & $p$ & $\tau$ & $p$ & $\tau$ & $p$ & $\tau$ & $p$ \\
\hline \multicolumn{9}{|c|}{ Panel A: Actual index } \\
\hline Spot & -1.64 & 0.77 & -13.20 & 0.00 & -1.71 & 0.74 & -13.17 & 0.00 \\
\hline \multicolumn{9}{|c|}{ Panel B: Implied index for Call options } \\
\hline ATM & -1.93 & 0.63 & -14.91 & 0.00 & -1.84 & 0.68 & -15.02 & 0.00 \\
\hline OTM & -1.68 & 0.76 & -12.54 & 0.00 & -1.82 & 0.69 & -12.43 & 0.00 \\
\hline ITM & -1.78 & 0.71 & -15.20 & 0.00 & -1.75 & 0.73 & -15.27 & 0.00 \\
\hline DOTM & -1.77 & 0.72 & -13.36 & 0.00 & -1.84 & 0.68 & -13.34 & 0.00 \\
\hline DITM & -1.29 & 0.89 & -14.85 & 0.00 & -1.21 & 0.91 & -14.88 & 0.00 \\
\hline \multicolumn{9}{|c|}{ Panel C: Implied index for Put options } \\
\hline ATM & -1.83 & 0.69 & -15.48 & 0.00 & -1.66 & 0.76 & -15.69 & 0.00 \\
\hline OTM & -1.61 & 0.78 & -15.28 & 0.00 & -1.48 & 0.83 & -15.48 & 0.00 \\
\hline ITM & -1.77 & 0.71 & -14.21 & 0.00 & -1.76 & 0.72 & -14.32 & 0.00 \\
\hline DOTM & -1.05 & 0.93 & -15.32 & 0.00 & -0.62 & 0.98 & -15.44 & 0.00 \\
\hline DITM & -1.74 & 0.73 & -9.31 & 0.00 & -1.78 & 0.71 & -14.01 & 0.00 \\
\hline
\end{tabular}


Appendix 4: Results of ARCH LM Test for Heteroskedasticity

\begin{tabular}{lrrrc}
\hline & F Stat. & $\boldsymbol{p}$ & Chi Sq. & $\boldsymbol{p}$ \\
\hline Panel A: Actual index & & & & \\
\hline Spot & 11.17 & 0.00 & 20.32 & 0.00 \\
\hline Panel B: Implied index for Call options & & & & \\
\hline ATM & 2.15 & 0.08 & 8.43 & 0.08 \\
OTM & - & - & - & - \\
ITM & 1.51 & 0.07 & 34.02 & 0.08 \\
DOTM & - & - & - & - \\
DITM & 3.27 & 0.00 & 31.82 & 0.00 \\
\hline Panel C: Implied index for Put options & & & & \\
\hline ATM & 9.11 & 0.00 & 8.79 & 0.00 \\
OTM & 4.67 & 0.00 & 13.33 & 0.00 \\
ITM & - & - & - & - \\
DOTM & 4.69 & 0.00 & 25.34 & 0.00 \\
DITM & 14.81 & 0.00 & 26.05 & 0.00 \\
\hline
\end{tabular}

Appendix 5: Estimation Results of Diagonal BEKK GARCH Model

\begin{tabular}{|c|c|c|c|c|c|c|c|c|c|c|}
\hline & \multicolumn{2}{|c|}{ ATM } & \multicolumn{2}{|c|}{ OTM } & \multicolumn{2}{|c|}{ ITM } & \multicolumn{2}{|c|}{ DOTM } & \multicolumn{2}{|c|}{ DITM } \\
\hline & Coeff. & $p$ & Coeff. & $p$ & Coeff. & $p$ & Coeff. & $p$ & Coeff. & $p$ \\
\hline \multicolumn{11}{|c|}{ Panel A: Call Options } \\
\hline$C^{\prime}$ & 0.00 & 0.57 & - & - & 0.00 & 0.22 & - & - & 0.00 & 0.00 \\
\hline C & 0.00 & 0.44 & - & - & 0.00 & 0.18 & - & - & -0.01 & 0.00 \\
\hline$H_{s s, t}$ & 0.00 & 0.03 & - & - & 0.00 & 0.01 & - & - & 0.00 & 0.00 \\
\hline$H_{s o, t}$ & 0.00 & 0.04 & - & - & 0.00 & 0.00 & - & - & 0.00 & 0.00 \\
\hline$H_{o o, t}$ & 0.00 & 0.05 & - & - & 0.00 & 0.01 & - & - & 0.00 & 0.00 \\
\hline$\alpha_{11}^{*}$ & 0.62 & 0.00 & - & - & 0.57 & 0.00 & - & - & 0.66 & 0.00 \\
\hline$\alpha_{22}^{*}$ & 0.53 & 0.00 & - & - & 0.48 & 0.00 & - & - & 0.40 & 0.00 \\
\hline$\beta_{11}^{*}$ & 0.82 & 0.00 & - & - & 0.85 & 0.00 & - & - & 0.82 & 0.00 \\
\hline$\beta_{22}^{*}$ & 0.87 & 0.00 & - & - & 0.88 & 0.00 & - & - & 0.88 & 0.00 \\
\hline & & & & & & & & & \multicolumn{2}{|c|}{ (Contd.) } \\
\hline
\end{tabular}




\begin{tabular}{lccccccccccc}
\hline & \multicolumn{2}{c}{ ATM } & \multicolumn{2}{c}{ OTM } & \multicolumn{2}{c}{ ITM } & \multicolumn{2}{c}{ DOTM } & \multicolumn{2}{c}{ DITM } \\
\hline \multicolumn{3}{c}{ Coeff. } & $\boldsymbol{p}$ & Coeff. & $\boldsymbol{p}$ & Coeff. & $\boldsymbol{p}$ & Coeff. & $\boldsymbol{p}$ & Coeff. & $\boldsymbol{p}$ \\
\hline \multicolumn{2}{l}{ Panel B: Put Options } & & & & & & & & & \\
\hline$C^{\prime}$ & 0.00 & 0.14 & 0.00 & 0.23 & - & - & 0.00 & 0.01 & 0.00 & 0.23 \\
$C$ & 0.00 & 0.13 & 0.00 & 0.25 & - & - & -0.01 & 0.01 & 0.00 & 0.27 \\
$H_{s s, t}$ & 0.00 & 0.03 & 0.00 & 0.00 & - & - & 0.00 & 0.01 & 0.00 & 0.08 \\
$H_{s o, t}$ & 0.00 & 0.02 & 0.00 & 0.00 & - & - & 0.00 & 0.00 & 0 & 0.08 \\
$H_{o o, t}$ & 0.00 & 0.02 & 0.00 & 0.03 & - & - & 0.00 & 0.01 & 0.00 & 0.08 \\
$\alpha_{11}^{*}$ & 0.41 & 0.00 & 0.47 & 0.00 & - & - & 0.51 & 0.00 & 0.35 & 0.00 \\
$\alpha_{22}^{*}$ & 0.54 & 0.00 & 0.31 & 0.00 & - & - & 0.35 & 0.00 & 0.36 & 0.00 \\
$\beta_{11}^{*}$ & 0.89 & 0.00 & 0.87 & 0.00 & - & - & 0.88 & 0.00 & 0.90 & 0.00 \\
$\beta_{22}^{*}$ & 0.80 & 0.00 & 0.90 & 0.00 & - & - & 0.92 & 0.00 & 0.91 & 0.00 \\
\hline
\end{tabular}

Note: The D-BEKK GARCH model estimated here is

$H_{t}=\left(\begin{array}{cc}H_{s s, t} & H_{s j, t} \\ H_{j s, t} & H_{j j, t}\end{array}\right)=C^{\prime} C+\sum_{k=1}^{p} \alpha_{k}^{\prime} u_{t-k} u_{t-k}^{\prime} \alpha_{k}+\sum_{k=1}^{p} \beta_{k}^{\prime} H_{t-k} \beta_{k}$ 